\title{
Superoxide production by polymorphonuclear leucocytes in rheumatoid arthritis and osteoarthritis: in vivo inhibition by the antirheumatic drug piroxicam due to interference with the activation of the NADPH-oxidase
}

\author{
P BIEMOND, ${ }^{12}$ A J G SWAAK, ${ }^{3} \mathrm{~J} \mathrm{M} \mathrm{A} \mathrm{PENDERS},{ }^{4} \mathrm{C}$ M BEINDORFF, ${ }^{1}$ \\ AND J F KOSTER ${ }^{1}$
}

From the ${ }^{1}$ Department of Biochemistry I, Medical Faculty, Erasmus University Rotterdam, Rotterdam, The Netherlands; the ${ }^{2}$ Department of Internal Medicine III, Academical Hospital 'Dijkzigt', Rotterdam, The Netherlands; the ${ }^{3}$ Department of Rheumatology, Daniël den Hoed Clinic, Rotterdam, The Netherlands; and the ${ }^{4}$ Medical Service, Pfizer BV, Rotterdam, The Netherlands

SUMmARY The superoxide $\left(\mathrm{O}_{2}{ }^{-}\right)$production of stimulated polymorphonuclear leucocytes is increased in patients with rheumatoid arthritis and osteoarthritis compared with controls. Treatment of these different groups with pharmacological amounts of the non-steroidal antiinflammatory drug piroxicam in vivo resulted in a decrease of about $25 \%$ in $\mathrm{O}_{2}^{-}$secretion by isolated granulocytes. In vitro experiments showed that piroxicam inhibits $\mathrm{O}_{2}{ }^{-}$production of granulocytes by interference with the stimulation of the NADPH-oxidase. Piroxicam caused diminished $\mathrm{O}_{2}{ }^{-}$production of membrane fragments if it was present during the stimulation of the NADPH-oxidase of the intact cells. During the actual $\mathrm{O}_{2}{ }^{-}$production of the stimulated membrane fragments piroxicam had no effect. It is concluded that piroxicam is able to inhibit granulocyte $\mathrm{O}_{2}^{-}$production by blocking the activation of NADPH-oxidase, which results in diminished tissue destruction by oxygen free radicals in inflammatory diseases.

Key words: granulocyte inhibition, mechanism of NSAIDs, granulocyte membrane fragments, superoxide anion, phagocytosis.

The importance of oxygen free radicals and related activated oxygen intermediates in the pathogenesis of rheumatoid arthritis (RA) is increasingly recognised. ${ }^{1-4}$ In $\mathrm{RA}$ and in other inflammatory diseases polymorphonuclear leucocytes (PMN) and macrophages are stimulated, which results in the secretion of inflammatory mediators, including large amounts of superoxide $\left(\mathrm{O}_{2}{ }^{-}\right)$and hydrogen peroxide $\left(\mathrm{H}_{2} \mathrm{O}_{2}\right){ }^{5}$ These cells produce $\mathrm{O}_{2}^{-}$by the NADPH-oxidase, an enzyme complex located in the plasma membrane and phagosome. The reduction equivalents to reduce oxygen to $\mathrm{O}_{2}{ }^{-}$are derived from NADPH. In the non-phagocytosing cell the

Accepted for publication 9 August 1985.

Correspondence to Dr J F Koster, Department of Biochemistry I, Erasmus University, PO Box 1738, 3000 DR Rotterdam. The Netherlands.
NADPH-oxidase is inactive. When the cell is stimulated to phagocytose an activation mechanism for NADPH-oxidase is triggered. Little is known about the molecular basis of this activation mechanism. These activated oxygen intermediates together with secondary formed radicals, like the hydroxyl radical $\left(\mathrm{OH}^{-}\right)$, are able to destroy membrane lipids, proteins, deoxyribonucleic acid, hyaluronic acid, and cartilage. 367 Previous investigations have shown that different antirheumatic drugs are able to inhibit the production of oxygen free radicals. ${ }^{8-10}$ Thus it is reasonable to believe that non-steroidal anti-inflammatory drugs (NSAIDs) have a beneficial effect not only by the inhibition of cyclooxygenase, as shown by the excellent work of Vane ${ }^{11}$ but also by preventing the formation of oxygen free radicals. 
Until now the inhibition of the $\mathrm{O}_{2}^{-}$producing NADPH oxidase by NSAIDs has been mostly tested in vitro. This study is focused on the in vivo inhibition of $\mathrm{O}_{2}^{-}$production from PMN by piroxicam, which was chosen because of the encouraging results already obtained. ${ }^{12-14} \mathrm{O}_{2}^{-}$production of PMN was tested before and at different times after the administration of piroxicam to patients with RA and osteoarthritis, and to controls. Attention was also given to the molecular level at which piroxicam interferes with the NADPH-oxidase.

\section{Patients and methods}

\section{PAT IEN TS}

PMN were isolated at different times from patients with classical or definite RA, from patients with osteoarthritis, and from healthy volunteers. Patients on D-penicillamine, gold salts, or corticosteroids were excluded. All other drugs were discontinued three days before administering piroxicam. If necessary paracetamol was allowed.

Piroxicam was given orally, $40 \mathrm{mg}$ at time zero and another $20 \mathrm{mg} 24 \mathrm{~h}$ later. When blood was taken for PMN isolation a serum sample was also drawn, and the serum peroxicam was measured by high performance thin layer chromatography. ${ }^{15}$ Before and during the observation period no other NSAIDs were taken.

PMN ISOLATION

PMN were harvested from defibrinated blood by sodium metrizoate-Ficoll centrifugation (Lymphoprep, Nyegaard \& Co., Oslo, Norway). Erythrocytes were lysed by a cold isotonic $\mathrm{NH}_{4} \mathrm{Cl}$ solution. ${ }^{16}$ The final cell suspension contained $>95 \%$ PMN. At least $95 \%$ of the cells were viable, based on the exclusion of trypan blue.

CAPACITY OF PMN TO PRODUCE $\mathrm{O}_{2}^{-}$

Isolated $\mathrm{PMN}$ were measured for their capacity to produce $\mathrm{O}_{2}^{-}$by the cytochrome $c$ reduction method. The isolated cells were resuspended in a solution containing: $137 \mathrm{mM} \mathrm{NaCl}, 5.4 \mathrm{mM} \mathrm{KCl}$, $0.7 \mathrm{mM} \mathrm{NaH}_{2} \mathrm{PO}_{4}, 0.8 \mathrm{mM} \mathrm{MgSO}_{4}, 1.3 \mathrm{mM} \mathrm{CaCl}_{2}$, $5.5 \mathrm{mM}$ glucose, $25 \mathrm{mM}$ trometamol (TRIS) (pH 7.4 at $37^{\circ} \mathrm{C}$ ), and $5 \mathrm{~g} / 1$ of bovine serum albumin. The incubation mixture contained in final concentrations: $0.7 \times 10^{6} \mathrm{PMN} / \mathrm{ml}\left(0.7 \times 10^{9} / 1\right)$ exactly, $150 \mu \mathrm{M}$ cytochrome $c$, and as stimulus $100 \mu \mathrm{g} / \mathrm{l}$ phorbol myristate acetate (PMA) or $1 \mathrm{~g} / \mathrm{l}$ serum treated zymosan. After $15 \mathrm{~min}$ at $37^{\circ} \mathrm{C}$ absorption at $550 \mathrm{~nm}$ was measured. The $\mathrm{O}_{2}^{-}$production was calculated from the increase of the absorption by using an extinction coefficient of 21100 litre $\mathrm{mol}^{-1} \mathrm{~cm}^{-1}$ for cytochrome $c$. Control experiments showed that cytochrome $c$ reduction was completely blocked by the addition of $13 \mathrm{mg} / \mathrm{l}$ superoxide dismutase.

For measurements of the effect of piroxicam ins? vitro PMN were obtained from healthy individualso Cells were resuspended in: $138 \mathrm{mM} \mathrm{NaCl}, 2.7 \mathrm{mM}$ $\mathrm{KCl}, 8 \cdot 1 \mathrm{mM} \mathrm{Na}_{2} \mathrm{HPO}_{4}, 1.5 \mathrm{mM} \mathrm{KH} \mathrm{PO}_{4}, 1 \mathrm{mM}$ $\mathrm{MgCl}_{2}, 0.6 \mathrm{mM} \mathrm{CaCl}, \mathrm{pH} 7.4$ (PiCM buffer) Incubations were performed with $3.0 \times 10^{6} \mathrm{PMN} / \mathrm{mbu}$ $\left(3.0 \times 10^{9} / 1\right)$. Piroxicam (Pfizer BV Rotterdam, The Netherlands) was dissolved in $1 \mathrm{M} \mathrm{NaOH}$, followed by correction of the $\mathrm{pH}$, to final concentrations of 25,50 , and $100 \mu \mathrm{mol} / 1$. After $5 \mathrm{~min}$ preincubation $\left(37^{\circ} \mathrm{C}\right) 150 \mu \mathrm{M}$ cytochrome $c$ and $200 \mu \mathrm{g} / \mathrm{l}$ PMA were added (final concentrations). At different times samples were drawn and $\mathrm{O}_{2}{ }^{-}$production was measured.

$\mathrm{O}_{2}{ }^{-}$PRODUCTION BY MEMBRANE

F R A G M E N T S

Membrane fragments were isolated from controk persons according to Tauber and Goetzl. ${ }^{17}$ Isolated PMN were preincubated with or without $100 \mu \mathrm{M}$ ? piroxicam for $5 \mathrm{~min}$. This was followed by stimu $\overrightarrow{0}$ lation of the cells by incubation with $1 \mathrm{mg} / 1$ PMA foळ three minutes at $37^{\circ} \mathrm{C}$. Cells were homogenised at $0^{\circ} \mathrm{C}$ and differential centrifugation followed. $\mathrm{O}_{2} \stackrel{\mathrm{O}}{\mathrm{S}}$ production was measured in a mixture containing PMN membrane fragments $10 \mu \mathrm{g}$ protein $/ \mathrm{ml}(\mathrm{mg} / \mathrm{l} / \mathrm{h}$ in PiCM buffer, $1 \mathrm{mM}$ NADPH, and $150 \mu \mathrm{M}$ cytochrome $c$. The absorbance was measured at $550^{\mathcal{Q}}$ $\mathrm{nm}$ in a double beam spectrophotometer. The effecto

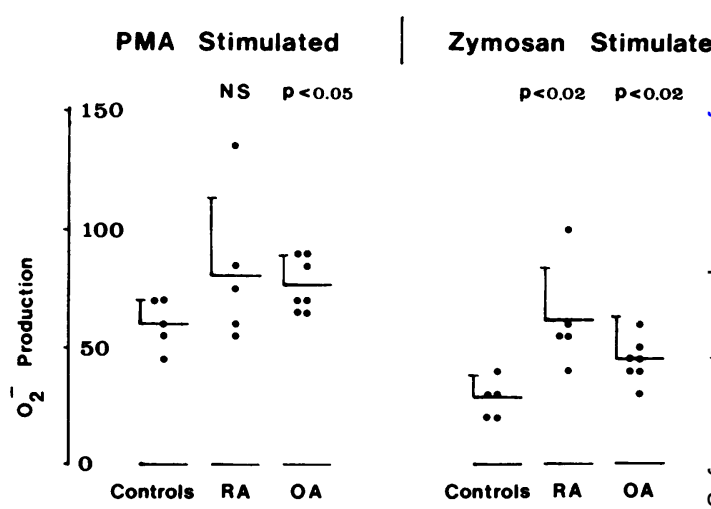

Fig. $1 \mathrm{O}_{2}^{-}$production by stimulated PMN from: controls $(n=5)$, patients with rheumatoid arthritis $(R A)(n=5)$, and patients with osteoarthritis $(O A)(n=7)$. Mean and $S D$ of $\mathrm{O}_{2}{ }^{-}$production are expressed as nmol/10 $10^{\circ} \mathrm{PMN}$ in 15 minutes. PMA or serum treated zymosan was used as stimulus. Significant differences with the control group are indicated. NS= not significant. 
of the addition of $100 \mu \mathrm{M}$ piroxicam during the $\mathrm{O}_{2}{ }^{-}$ production was also studied. All measurements were duplicated.

\section{Results}

$\mathrm{O}_{2}^{-}$PRODUCTION OF PMN ISOLATED FROM PATIENTS WITH UNTREATED RA AND OSTEOARTHRITIS, AND FROM CONTROLS At two different times with an interval of $24 \mathrm{~h}$ PMN were isolated from blood from patients with RA and osteoarthritis, and from healthy controls, before treatment with piroxicam. Without stimulation of the cells only very small amounts of $\mathrm{O}_{2}{ }^{-}$were secreted, without difference between the groups. The $\mathrm{O}_{2}{ }^{-}$production after stimulation with either PMA or serum treated zymosan is presented in Fig. 1. The mean production of the two different PMN isolations from each individual is shown. After stimulation with PMA no significant difference in $\mathrm{O}_{2}{ }^{-}$production was found between RA patients and controls. In contrast, patients with osteoarthritis produced $129 \% \mathrm{O}_{2}{ }^{-}$in comparison with controls $(p<0 \cdot 05)$. After stimulation with serum treated zymosan $\mathrm{O}_{2}^{-}$secretion was significantly higher in both RA and osteoarthritis patients and equalled $212 \%(p<0.02)$ and $154 \%(p<0.02)$ respectively.
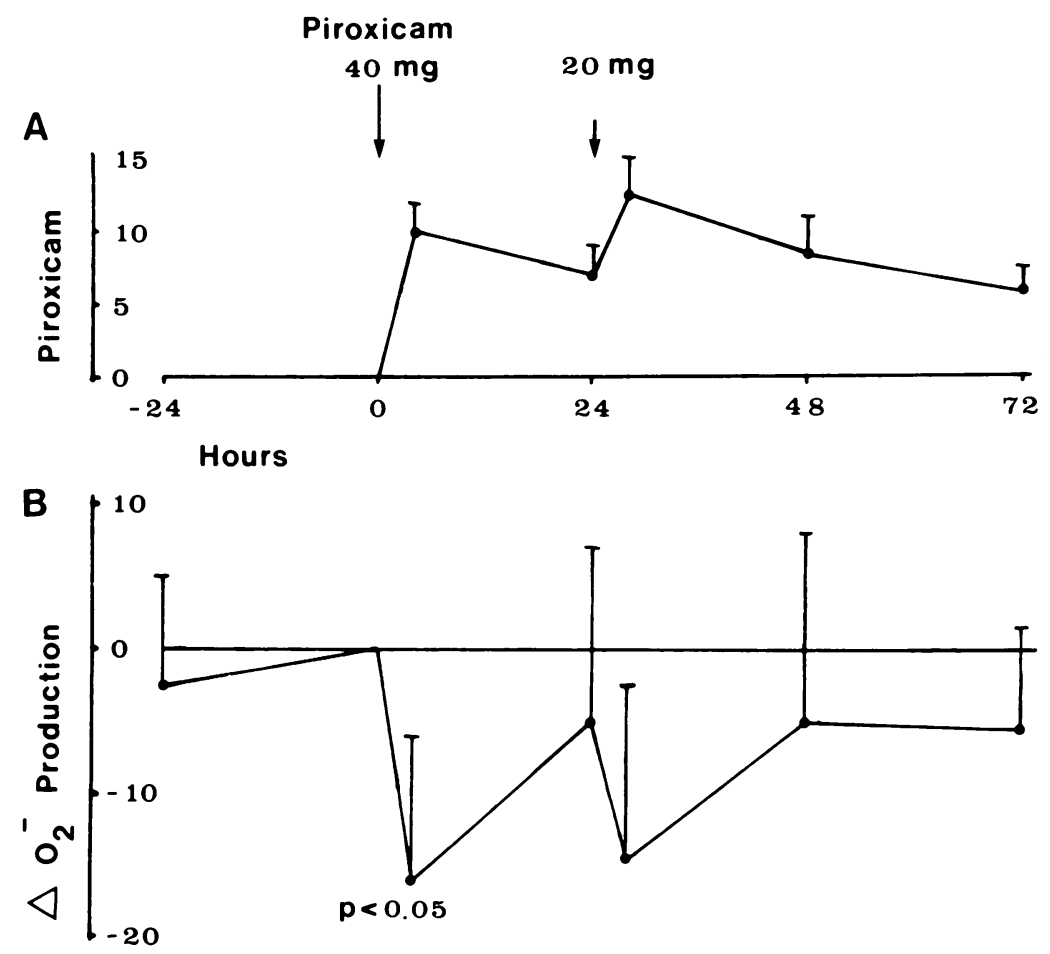

Fig. 2 The effect of piroxicam administered to control persons $(n=5)$ on the $\mathrm{O}_{2}^{--}$production by stimulated PMN isolated at different times. (A) Piroxicam concentration in $\mu \mathrm{mol} / \mathrm{l}$; (B) $\mathrm{O}_{2}$ production of $P M N$ stimulated with $\mathrm{PMA}$; (C) $\mathrm{O}_{2}$ production of $P M N$ stimulated with serum treated zymosan. $\mathrm{O}_{2}$ production (in nmol/10 $P M N$ in 15 minutes) is expressed as the difference in the $\mathrm{O}_{2}$ production at the indicated time and at time zero. Mean and $S D$ are shown. Significant differences are indicated.

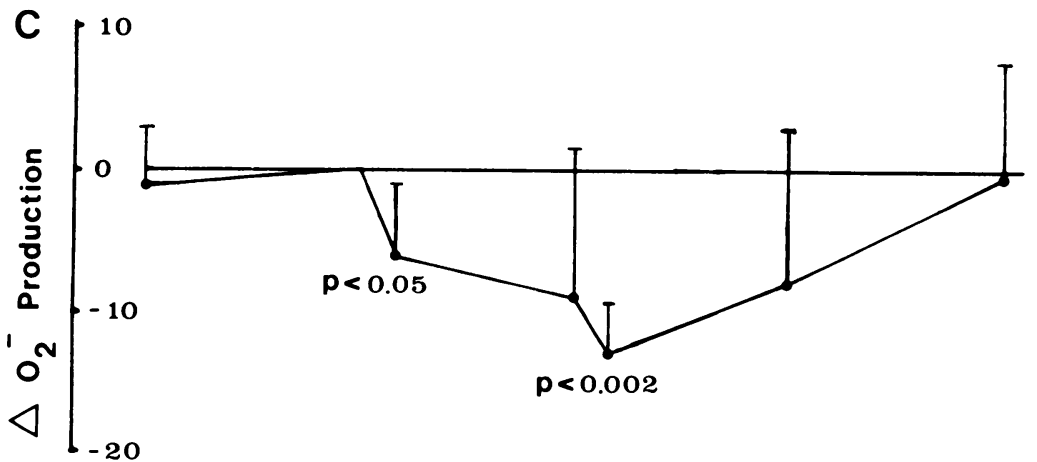


$\mathrm{O}_{2}^{-}$PRODUCTION OF PMN ISOLATED AFTER TREATMENT WITH PIROXICAM IN VIVO

The effect of administering piroxicam orally on the $\mathrm{O}_{2}{ }^{-}$production of $\mathrm{PMN}$ isolated after treatment was measured in RA and osteoarthritis patients and in healthy controls. Piroxicam was taken orally at two times, $40 \mathrm{mg}$ at time zero and another $20 \mathrm{mg} 24$ h later. At the times indicated PMN were isolated and $\mathrm{O}_{2}{ }^{-}$production after stimulation with PMA ow. serum treated zymosan was determined (Figs 2, 3. and 4). After taking the blood samples PMN were? washed five times so that no serum containing piroxicam was left during the $\mathrm{O}_{2}{ }^{-}$estimation. The isolation procedure took about $2 \frac{1}{2} \mathrm{~h}$. For each? individual the difference in $\mathrm{O}_{2}^{-}$production a民 various times was expressed in comparison with the

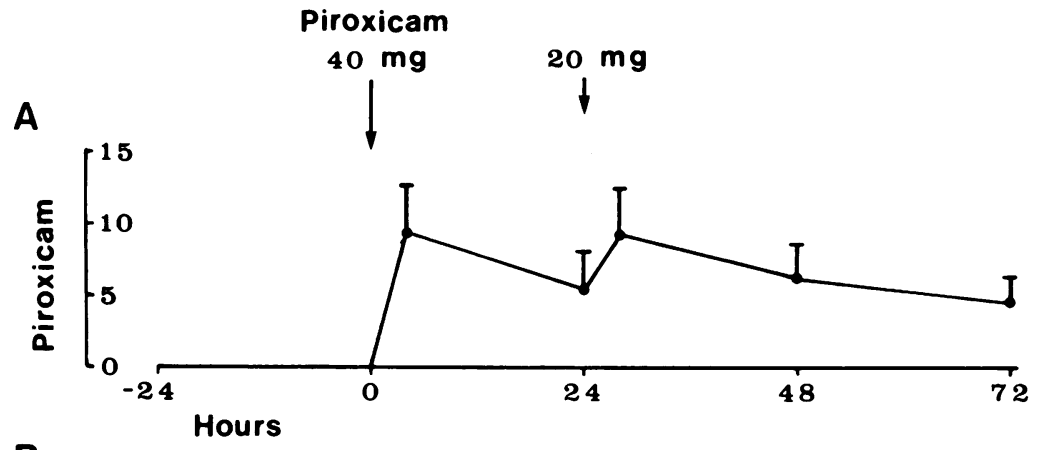

B

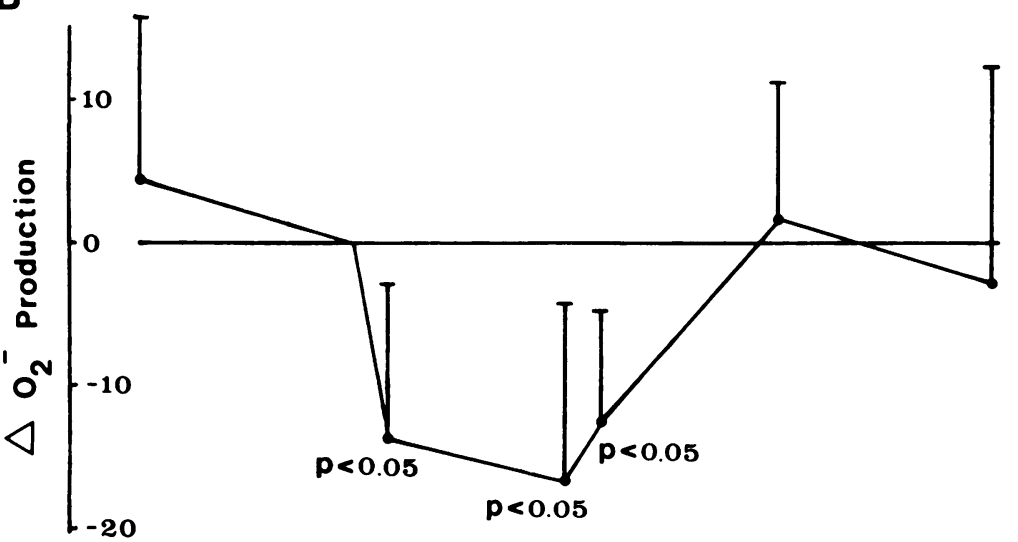

Fig. 3 The effect of piroxicam administered to $R A$ patients $(n=5)$ on the $\mathrm{O}_{2}^{-}$production by stimulated PMN isolated at different times. For further explanation see legend to Fig. 2.

C

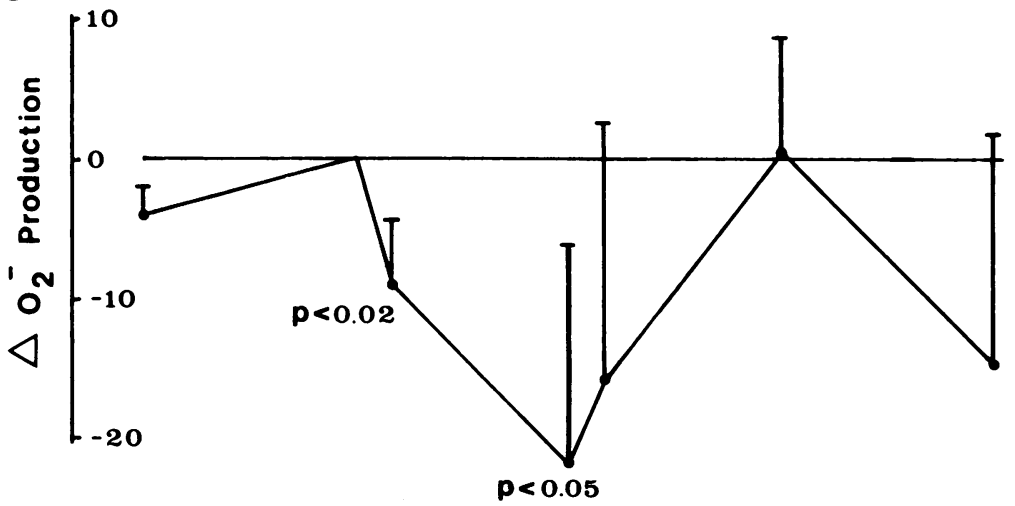


$\mathrm{O}_{2}^{-}$production at time zero, immediately before the first dose of piroxicam. This presentation was used to diminish the effect of variation in $\mathrm{O}_{2}{ }^{-}$ production before piroxicam treatment.

There was again very little $\mathrm{O}_{2}^{-}$production without stimulation of the cells with PMA or serum treated zymosan and this was not changed by piroxicam treatment (data not shown). In the control group $(n=5)$. (Fig. 2) there was a significant decrease in $\mathrm{O}_{2}^{-}$production four hours after taking $40 \mathrm{mg}$ piroxicam, which was independent of PMA or
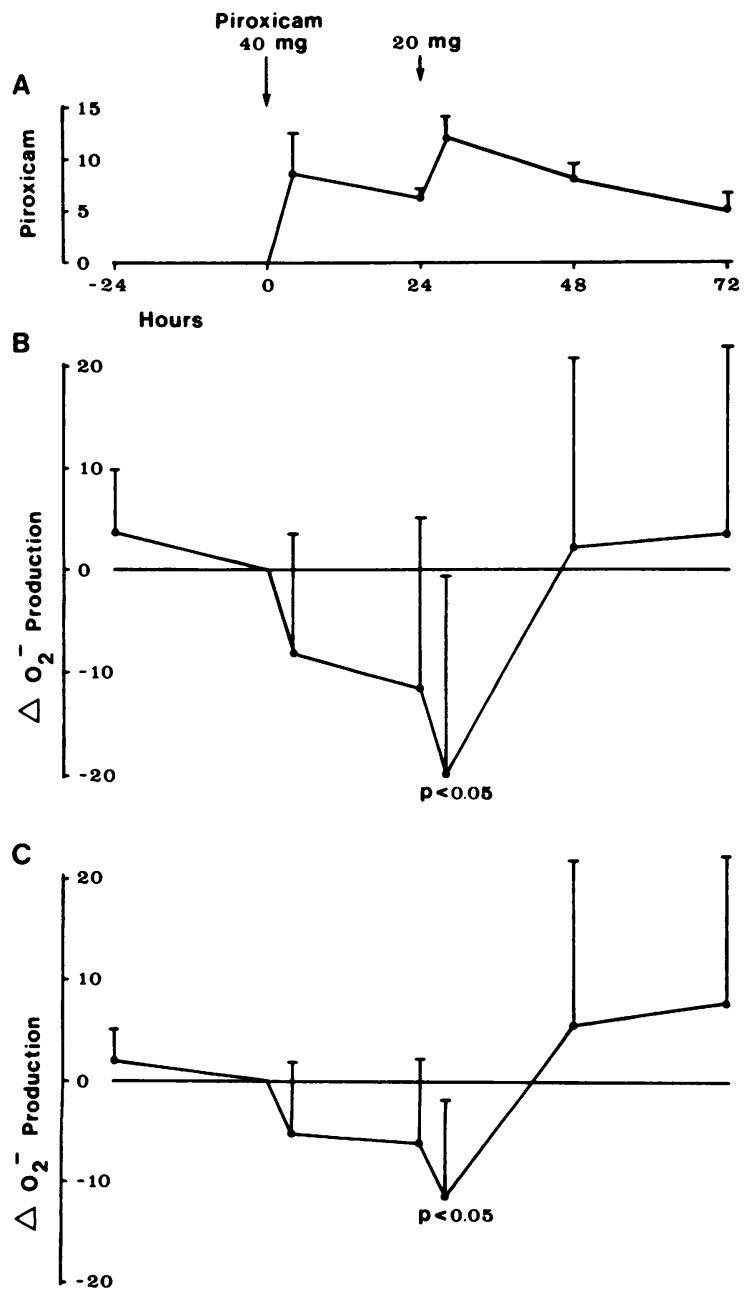

Fig. 4 The effect of piroxicam administered to osteoarthritis patients $(n=7)$ on the $\mathrm{O}_{2}^{-}$production by stimulated PMN isolated at different times. For further explanation see legend to Fig. 2. serum treated zymosan as stimulus. At 28 hours, four hours after the second dose of piroxicam (20 $\mathrm{mg}$ ), the $\mathrm{O}_{2}{ }^{-}$production was only significantly decreased when serum treated zymosan was used as stimulus. At 48 and 72 hours the $\mathrm{O}_{2}{ }^{-}$production approached the level before treatment. The data at $\mathrm{t}=-24$ hours indicate the variation of the $\mathrm{O}_{2}{ }^{-}$ production without treatment.

The RA patients $(n=5)$ (Fig. 3) showed similar results. Again piroxicam treatment induced a significant decrease in $\mathrm{O}_{2}{ }^{-}$production between four and 28 hours, which was followed by a return to the basal $\mathrm{O}_{2}{ }^{-}$production at 48 hours.

Patients with osteoarthritis $(n=7)$ (Fig. 4) showed the same pattern, but the decrease in $\mathrm{O}_{2}{ }^{-}$production was significant only at 28 hours.

No significant change in $\mathrm{O}_{2}^{-}$production was found in controls without piroxicam treatment in a period of four days, and no diurnal variation was found.

The effect of piroxicam was essentially the same in all different groups. Treatment with pir oxicam resulted in an average decrease in $\mathrm{O}_{2}{ }^{-}$production of $25 \%$. It should be noted that owing to the extensive washing during the cell isolation, no serum containing piroxicam was left during the $\mathrm{O}_{2}^{-}$measurements. It can be concluded that piroxicam treatment in vivo changed the ability of isolated PMN to produce $\mathrm{O}_{2}^{-}$.

LEVEL OF INTERACTION OF PIROXICAM WITH THE NADPH-OXIDASE OF PMN Fig. 5 shows that the inhibition of $\mathrm{O}_{2}^{-}$production of intact PMN by piroxicam was dependent on concentration. To identify the mode of inhibition of the

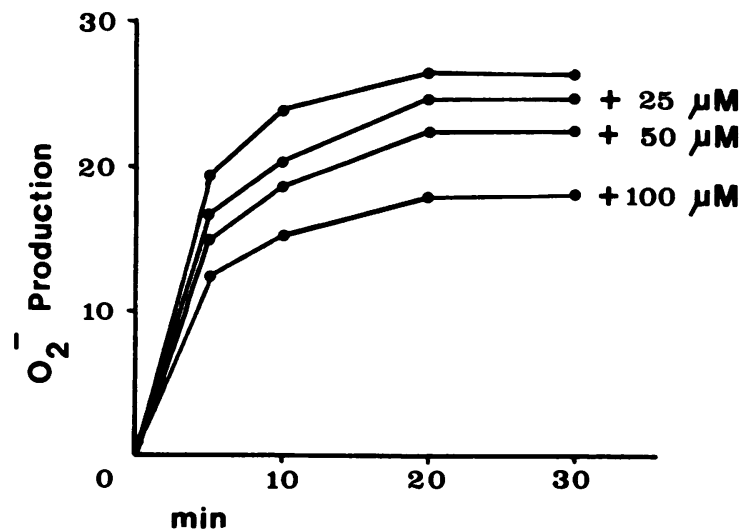

Fig. 5 The in vitro inhibition of $\mathrm{O}_{2}^{-}$production $\left(\mathrm{nmol} / 10^{6}\right.$ $P M N$ in 15 minutes) of PMN stimulated by PMA incubated in presence of various piroxicam concentrations. 


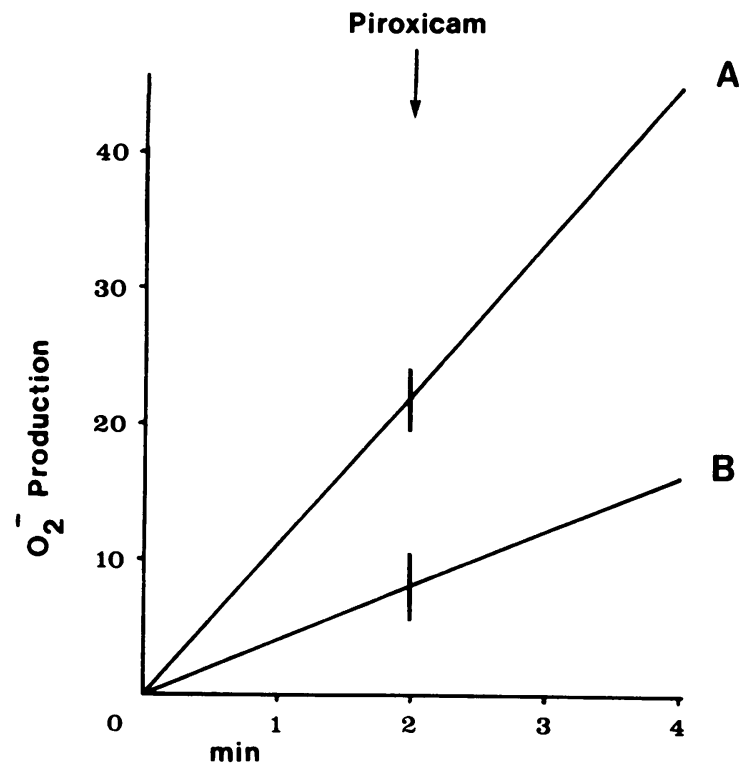

Fig. $6 \mathrm{O}_{2}^{-}$production (nmol/mg protein) by membrane fragments of PMN stimulated by PMA. During stimulation of the NADPH-oxidase of the intact PMN $100 \mu M$ piroxicam was absent in $A$ and present in $B$. The effect of $100 \mu \mathrm{M}$ piroxicam during the $\mathrm{O}_{2}{ }^{-}$production is also shown (addition indicated by an arrow)

$\mathrm{O}_{2}^{-}$producing NADPH-oxidase complex PMN were homogenised after stimulation of the NADPHoxidase with PMA. The capacity of membrane fragments to produce $\mathrm{O}_{2}^{-}$was not changed by the addition of $100 \mu \mathrm{M}$ piroxicam during the $\mathrm{O}_{2}{ }^{-}$ production (Fig. 6). Membrane fragments obtained from PMN stimulated with PMA in the presence of piroxicam produced smaller amounts of $\mathrm{O}_{2}{ }^{-}$in comparison with fragments of cells stimulated in the absence of piroxicam. Addition of piroxicam to these membrane fragments did not result in enhanced inhibition. These results indicate that piroxicam has no effect on the NADPH-oxidase complex itself if it is already stimulated, but that piroxicam interferes in the mechanism by which the NADPHoxidase is stimulated.

\section{Discussion}

The exact role of oxygen free radicals in the pathogenesis of RA is not yet established. However, many authors are convinced that these radicals have an important role. ${ }^{1-4}$ Phagocytosing granulocytes are known to produce considerable amounts of $\mathrm{O}_{2}{ }^{-}$ and $\mathrm{H}_{2} \mathrm{O}_{2}$. ${ }^{\prime}$ In juvenile RA stimulated granulocytes are shown to produce twice as much $\mathrm{O}_{2}^{-}$as control
PMN. ${ }^{18}$ No difference in $\mathrm{O}_{2}{ }^{-}$production was found between adult RA patients and controls, ${ }^{17}$ but the $\Rightarrow$ study of Chiu et al. showed that PMN from patients with Felty's syndrome produced only $63 \% \quad \mathrm{O}_{2}{ }^{-}$음 compared with the controls. ${ }^{19}$ The present investi-ㅡㅡㅁ gations show that after stimulation with serum? treated zymosan PMN from patients with RA or尺 osteoarthritis produce an increased amount of $\mathrm{O}_{2}{ }^{-} \mathrm{\infty}$ compared with controls. With PMA stimulated $\vec{\circ}$ PMN the increase was only significant in theosteoarthritis group. This increased potency of $\mathrm{PMN}_{\omega} \vec{\omega}$ to produce $\mathrm{O}_{2}{ }^{-}$together with the availability of stimulating factors for PMN in serum and synovialo fluid of RA patients ${ }^{20}$ will result in considerable $\mathrm{O}_{2}{ }^{-} \mathrm{e}$ production in vivo. In the presence of non-protein $\dot{\omega}$ bound iron, possibly derived from ferritin, ${ }^{21}$ forma- $N$ tion of the very toxic hydroxyl radical has to beco expected, and tissue destruction will result.

The discovery of the inhibition of prostaglandinsynthesis by NSAIDs, due to inhibition of cyclo-? oxygenase, indicated an important mechanism of action of NSAIDs. At this moment, however, it ${ }^{\supset}$ seems very likely that in addition other mechanisms $\overrightarrow{0}$ have a role in the beneficial effect of these drugs. $\odot$ Previous investigations have shown that NSAIDslike indomethacin, ibuprofen, phenylbutazone and piroxicam $^{8-12}$ are able in vitro to decrease the release of $\mathrm{O}_{2}{ }^{-}$from PMN. Abramson et al. ${ }^{13}{ }^{14} \mathrm{~g}$ showed that piroxicam did also inhibit $\mathrm{O}_{2}^{-}$pro- $\stackrel{\circ}{\mathbb{Q}}$ duction of $\mathrm{PMN}$ in vivo in healthy volunteers. In four RA patients no significant effect was found. ${ }^{22}$ 을 In these studies $\mathrm{O}_{2}{ }^{-}$production was measured only at two times-before and during treatment with piroxicam. The present study shows the effect of two doses of piroxicam, and $\mathrm{O}_{2}^{-}$production was measured at seven different times-twice before treatment to show the natural variation, at different times during the phase of high piroxicam serum $ᄋ$ levels, and during the recovery phase.

The results show that treatment of patients with응 piroxicam caused diminished $\mathrm{O}_{2}^{-}$production of $\supset$ their PMN. The average decrease was $25 \%$. In contrast with the studies of Abramson et al. ${ }^{13} 1422$ we found not only significant decrease in $\mathrm{O}_{2}^{-} \mathrm{-r}$ production in normals but also in RA and osteo- $N$ arthritis patients. For the different groups: RA N patients, osteoarthritis patients, and controls, nog essential differences in the inhibition patterns were found. During the recovery phase the $\mathrm{O}_{2}{ }^{-}$production showed a tendency to normalise. In vivo $\stackrel{?}{+}$ PMN probably are inhibited to a larger extent, 0 because the isolation procedure of the PMN lasted ${ }^{\circ}$

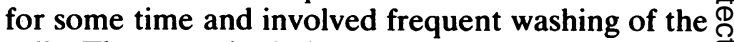
cells. These manipulations will possibly decrease the $\stackrel{\vec{D}}{\circ}$ effect of piroxicam on the cells. The conclusion can $\frac{}{\sigma}$ be drawn that in vivo piroxicam is able to decrease 
the $\mathrm{O}_{2}^{-}$production of $\mathrm{PMN}$ to a considerable extent.

To obtain information about the mechanism of inhibition investigations were performed on the level at which piroxicam inhibited the $\mathrm{O}_{2}^{-}$production of $\mathrm{PMN}$. Isolated membrane fragments were used, which are known to contain the $\mathrm{O}_{2}{ }^{-}$ producing NADPH-oxidase. Stimulation of the NADPH-oxidase is only possible in intact cells, possibly with the exception of stimulation with cis unsaturated fatty acids. ${ }^{23}$ For this reason cells were homogenised after stimulation of the NADPHoxidase with PMA, followed by isolation of the membrane fragments. The $\mathrm{O}_{2}^{-}$production of the PMA stimulated NADPH-oxidase of membrane fragments decreased if piroxicam was present during the activation of the NADPH-oxidase in the intact cells. Addition of piroxicam to the isolated membrane fragments had no effect on the $\mathrm{O}_{2}{ }^{-}$ production. It can therefore be concluded that piroxicam interferes in the mechanism by which the NADPH-oxidase is activated. For this reason piroxicam can potentially be very useful for investigations designed to elucidate the mechanism by which NADPH-oxidase is stimulated.

Overall it seems reasonable to believe that piroxicam, and possibly other NSAIDs, cause improvement in RA and osteoarthritis not only by inhibition of prostaglandin synthesis but also by decrease of the $\mathrm{O}_{2}^{-}$production of PMN and macrophages, which results in the prevention of tissue destruction caused by oxygen free radicals.

We wish to thank Pfizer for estimation of the piroxicam concentrations, Ms I Simon for assistance by obtaining the samples, Mrs E M W van Zaal de Korte for preparing the manuscript, Dr R N Lemon for correction of the English, and the Rotterdam Rheumatism Foundation for their support.

\section{References}

1 Halliwell B, Gutteridge J M C. Oxygen toxicity, oxygen radicals, transition metals and disease. Biochem $J$ 1984; 219: 1-14.

2 Lunec J, Halloran S P, White A G, Dormandy T L. Free-radical oxidation (peroxidation) products in serum and synovial fluid in rheumatoid arthritis. $J$ Rheumatol 1981; 8: 233-45.

3 Greenwald R A, Moy W W. Effect of oxygen-derived free radicals on hyaluronic acid. Arthritis Rheum 1980; 23: 455-63.

4 Blake D R, Hall N D, Bacon P A, Dieppe P A, Halliwell B, Gutteridge J M C. The importance of iron in rheumatoid disease. Lancet 1981; ii: 1142-4.

5 Babior B M, Kipnes R S, Curnutte J T. Biological defense mechanisms: the production. by leucocytes of superoxide, a potent bactericidal agent. J Clin Invest 1973; 52: 741-4.

6 Freeman B A, Crapo J D. Biology of disease. Free radicals and tissues injury. Lab Invest 1982; 47: 412-26.

7 Greenwald R A, Moy W W, Lazarus D. Degradation of cartilage proteoglycans and collagen by superoxide radical [Abstract]. Arthritis Rheum 1976; 19: 799.

8 Simchowitz L, Mehta J, Spilberg I. Chemotactic factor-induced generation of superoxide radicals by human neutrophils. Effect of metabolic inhibitors and anti-inflammatory drugs. Arthritis Rheum 1979; 22: 755-63.

9 Harth M, Keown P A, Orange J F. Monocyte dependent excited oxygen radical generation in rheumatoid arthritis: inhibition by gold sodium thiomalate. J Rheumatol 1983; 10: 701-7.

10 Gay J C, Lukens J N, English D K. Differential inhibition of neutrophil superoxide generation by non-steroidal antiinflammatory drugs. Inflammation 1984; 8: 209-22.

11 Vane J R. Inhibition of prostaglandin synthesis as a mechanism of action for aspirin like drugs. Nature New Biol 1971; 231: 232-5.

12 Edelson H S, Kaplan H B, Korchak H M, Smolen J E. Dissociation by piroxicam of degranulation and superoxide anion generation from decrements in chlortetracyclin fluorescence of activated human neutrophils. Biochem Biophys Res Commun 1982; 104: 247-53.

13 Abramson S, Edelson H, Kaplan H, Given W, Weissmann G. The inactivation of the polymorphonuclear leucocyte by non-steroidal anti-inflammatory drugs. Inflammation 1984; 8: s103-8.

14 Kaplan H B, Edelson H S, Korchak H M, Given W P, Abramson S, Weissman G. Effects of non-steroidal antiinflammatory agents on human neutrophil functions in vitro and in vivo. Biochem Pharmacol 1984; 33: 371-8.

15 Riedel K D, Laufen H. High-performance thin-layer chromatographic assay for the routine determination of piroxicam in plasma, urine and tissue. J Chromatogr 1983; 276: 243-8.

16 Weening R S, Roos D, Loos J A. Oxygen consumption of phagocytozing cells in human leukocyte and granulocyte preparations: a comparative study. J Lab Clin Med 1974; 83: 570-6.

17 Tauber A I, Goetzl E J. Structural and catalytic properties of the solubilized superoxide-generating activity of human polymorphonuclear leukocytes. Solubilization, stabilization in solution, and partial characterization. Biochemistry 1979; 18: 5576-84.

18 Rister M, Bauermeister K. Superoxid-Dismutase und Superoxid-Radikal-Freizetsung bei juveniler rheumatoider Arthritis. Klin Wochenschr 1982; 60: 561-5.

19 Chiu P L, Davis P, Wong K, Dasgupta M. Superoxide production in neutrophils of patients with rheumatoid arthritis and Felty syndrome. $J$ Rheumatol 1983; 10: 694-700.

20 Gale R, Bertouch J V, Bradley J, Roberts-Thomson P J. Direct activation of neutrophil chemiluminescence by rheumatoid sera and synovial fluid. Ann Rheum Dis 1983; 42: 158-62.

21 Biemond P, Van Eijk H G, Swaak A J G, Koster J F. Iron mobilization from ferritin by superoxide derived from stimulated polymorphonuclear leucocytes. Possible mechanism in inflammation diseases. $J$ Clin Invest 1984; 73: 1576-9.

22 Abramson S, Edelson H S, Kaplan H B, Ludewig R, Weissmann $\mathbf{G}$. Inhibition of neutrophil activation by nonsteroidal anti-inflammatory drugs. Am J Med 1984; 77: 3-6.

23 Curnutte J T, Badwey J A, Robinson J M, Karnovsky M J, Karnovsky M L. Studies on the mechanism of superoxide release from human neutrophils stimulated with arachidonate. $J$ Biol Chem 1984; 259: 11851-7. 